\title{
Leading accessible cinema across Europe
}

\author{
Pilar Orero \\ Universitat Autònoma de Barcelona, Spain
}

\begin{abstract}
To say cinema production, distribution, and exhibition is going through a paradigma shift is an understatement - and that is not taking into consideration COVID19. Adding EU accessibility requirements, in a multi lingual Europe elevates the pressure to all sectors of the film industry: from script writing, subtitlers to online ticketing. The European Council signed in 2006 the United Nations Convention on the Rights of Person with Disabilities (CRPD). This means a double obligation to all EU countries to fulfil CRPD since separately each EU country has also signed it. This means each country has to comply with the UN and EU will supervise and regulate through the European Regulators Group for Audiovisual Media (ERGA). This article describes the EU legal requirements regarding media accessibility. It will then describe the most popular accessibility services for media content, and it will finish describing the new network funded to help to adapt and fulfil EU legislation towards cinema for all.
\end{abstract}

Keywords: Accessibility, Human Rights, People with disability, Universal Design, Subtitling, Audio Description, Sign Language Interpreting

\section{Introduction}

Though cinema is a specific format of media content, the boundaries with other media genres is blurring fast. TV series are these days premiered in Film Festivals, for example Top of the Lake (2013) at Cannes, directed by Jane Campion. Movies are now produced and distributed by TV streaming platforms, and can be consumed by any device: TV, mobile phones, and tablets. For these reasons cinema falls in the media sector which is relevant to the new EU legislation and standards related to Media Accessibility.

The EU Media Sector is still far to meet the UN requirements set by Art.30 and 21 of the Convention on the Rights of Person with Disabilities (2006). The Convention recommends the full participation in cultural life, recreation and leisure for persons with disability which should enjoy access to cultural materials, to television programs, films, theatre and others in accessible formats, and through the Internet. Europe is a signatory of this convention, and for this reason some legislation was developed recently to fulfil the UN Convention:

1. The European Union (EU) Directive on the Accessibility of Websites and Mobile Applications. This directive requests from all EU member states to meet common accessibility standards in public bodies websites and mobile apps. This Directive was transposed into the laws of each EU member state by September 2018. The Directive is based on the Web Content Accessibility Guidelines (WCAG) 2.0 four steps: "Perceivable, Operable, Understandable, and Robust". The Directive references EN 301549 as the standard which will enable websites and apps to comply with the law. The schedule for compliance across EU countries is:

- September 2019 new public sector websites

- September 2020 all public sector websites

- September 2021 all public sector mobile apps

2. The Audiovisual Media Services Directive (AVMSD) governs EU-wide coordination of national legislation on all audio-visual media both traditional TV broadcasts and on-demand services. The directive was approved on 2018 and Member states will have 21 months to transpose it into national legislation. It provides:

- rules to shape technological developments

- creating a level playing field for emerging audiovisual media

- preserving cultural diversity

- protecting children and consumers

- safeguarding media pluralism

- combating racial and religious hatred

- guaranteeing the independence of national media regulators.

3. The European Accessibility Act is a law that would make many products and services in the European Union (EU) more accessible for persons with disabilities. The Accessibility Act takes the form of a Directive, which is legally binding, meaning that the EU Member States have an obligation to apply what the Act mentions. The Action foresees that only certain products and services need to be accessible:

- Smartphones, tablets and computers

- Ticketing machines and check-in machines

- Televisions and TV programmes

- Banking and ATMs

- E-books

- Online shopping websites and mobile applications

In order to comply with this new legislation, not only public sector organisations but also private companies and organisations will need to monitor the accessibility of their websites, mobile apps, and media content, and make information from the monitoring available in an accessibility statement. 
In the media sector limitations and barriers are still preventing full audiovisual media accessibility. The issues are related to usability, interoperability and standards, as well as lack of business-case for take-up by mainstream actors, legal barriers (for example for the transnational reuse of accessible content), difficulties in the reuse of accessible content over time and across different platforms. Additionally, the Media Access Research, in the next three years, will go through an intense change due to six factors:

1. The new EU legislation will trigger accessibility services deployment across Europe.

2. From the previous premise, minority languages will develop language technologies and automation.

3. Sound and audio are going through a change with spatial properties and object audio-based production.

4. Accessibility services will change the workflow to web-based.

5. Artificial Intelligence (Al) and Deep Learning will be applied to accessibility services.

6. Terminology shift from disability to competences leading to a widening scope for end-users: the aged, refugees, but also tourists.

With this context the agency for European Cooperation in Science and Technology (COST) has granted some funds for the next four years to create a network, called LEAD ME. This network offers an open space for collaboration among scientists and industry across Europe (and beyond) and thereby give impetus to research advancements and innovation on Media Accessibility.

\section{Accessibiity services for media content}

Media accessibility these days depends on technology -like everything else. Even the most basic and popular media accessibility service -subtitles- has these days different names and offer different services. In the past subtitles were translations with a condense text that appeared at the bottom of the screen in two lines (Egoyan and Balfour 2004). These days we have subtitles for the deaf and hard of hearing, or captions and closed captions, and they are not related to translations but for more or less verbatim transcriptions (Mas and Orero 2018). In the past media accessibility was defined by the end user who would benefit from the service: blind and low sighted people or deaf and hard of hearing people. These two groups had two large and very independent silos for both research and industry. The end user could not be aged and with sight and hearing issues. The end user could not have learning or literacy issues. The end user could not be someone in public transport with the sound turned off, or too far from the screen to be able to read, and many more cases. For this reason, rather than organising accessibility services by the needs of the end user, we can a very generic classification (Orero 2021).

Visual Accessibility - In this group we find services to challenge visual barriers. In general terms the alternative to visual input is an audio. These services are sound based, such as audio description, where images and sounds are narrated (Maszerowska et al 2016), audio subtitling where subtitles are read aloud (Orero et al 2020a), voice over (Franco et al 2010), text-to speech based services, and the new voice-command devices, which work on deep learning techniques and artificial intelligence.

Audio Accessibility - The services to challenge audio barriers are: subtitling, subtitling for the deaf and hard of hearing, transcriptions, Easy to Read, Clean audio, or Object based Audio (Más and Orero 2018). Subtitles are the translation of spoken language into text form for an audiovisual product. They should not be confused with subtitles for the deaf and hard of hearing $(\mathrm{SDH})$ or captions (as they are referred to in the US, Canada and Australia), which is the transcription of spoken words, sound effects, relevant musical cues and other relevant audio information to enable deaf or hard-of-hearing persons to follow an audiovisual programme. SDH may or may not involve translation from one language into another. Interlingual subtitles always do.

Interactive Accessibility - All media accessibility services may be open or closed. Open access services are always activated, and there is no personalisation. Since technology is increasingly allowing for personalisation (Mas and Orero 2018, Orero forthcoming) it means it has to be activated through the set up. This human interaction with the device where media is consumed also needs to be accessible. Otherwise we find the media content to have accessibility features, but the audience is unable to activate it. For this the media player, or the different voice commands on a smartphone are the way to activate the accessibility services (Brescia Zapata forthcoming).

Linguistic Accessibility - Linguistic barriers are posed by the language either in spoken, written, or signed. It may be related to reading from issues such as dyslexia, literacy, or by the writing system, for example a person who cannot read Japanese in Japan. Issues are also related to the language and its levels of complexity, or by the lack of understanding oral languages. The services to challenge linguistic barriers are translation and interpretation, including Sign Language services, but subtitling or audio description could also join this group, when the service is that of translating existing subtitles or audio description in text format. Easy to Read is also an accessibility service helping with the complex nature of readability, legibility and comprehension issues. As already mentioned, the possibility to mix accessibility services is today a reality. The movie Volver (Almodovar 2006) was distributed in English by DVD with audio subtitles and audio description together as one service. The original version was in Spanish with subtitles in English. Someone with sight issues would have had access to a movie in Spanish, and not being able to 
read the subtitles, would have been excluded from understanding the dialogue. Subtitles were offered for the dialogue translation, and audio description for the visual accessibility, still audio subtitling was required for those unable to read the subtitles.

These accessibility services are related to the movie itself, still accessibility is also related to all the other stages in the design, production, distribution, and exhibition of movies. Accessibility is also related to all the activities from buying a ticket to go to the cinema, or to make the payment online. While in the past accessibility services were sent as an open service for the general audience, these days mobile phones are being used and accessibility can be consumed anywhere (Oncins and Orero 2020). The distribution of accessibility services through the smart phone is a cheap and sustainable solution since the IT burden of buying, installing, and maintaining the receptor for accessibility is now attached to the audience who brings the mobile phone to the event. The mobile phone solution alleviates the costs of accessibility to exhibitors, still other stakeholders such as cinema producers are in need of adopting customisable solutions. To this aim the LEAD ME Cost Action was set up.

\section{The European network LEAD ME}

LEAD-ME (CA19142) was granted in 2020 and aims to help addressing this media accessibility European legal framework. LEAD ME will help towards meeting the legal milestones settled by international and national legislation by creating a fruitful collaboration among all stakeholders in the field of Media Accessibility and the cross-cutting topics (e.g. Al and Interactive Technologies). Researchers, filmmakers, media producers, engineers, scholars as well as businesses and policymakers will be empowered by LEAD-ME thanks a common and unique platform. During the next 48 months, LEAD-ME will collect, create, share, and disseminate innovative technologies and solutions, best practices and guidelines, and contribute to existing and new EU standards on Media Accessibility.

After the approval of the Memorandum of Understanding the Network, being inclusive, is opened to both COST and Non-COST Countries and organisations interested. This will empower and encourage researchers from Europe and Inclusiveness Target Countries to acquire new competencies thanks also to one of the tools: the Short-Term Scientific Missions. These are exchange visits between researchers involved in LEAD ME, allowing scientists to visit an institution or laboratory in another LEAD ME Member state. These scientific missions may last up to six months. Their aim is to foster collaboration in excellent research infrastructures and share new techniques that may not be available in a participant home institution or laboratory. LEAD-ME will encourage the EU Single Digital Market and avoid costly and senseless duplications.
The Action will impact and influence on Short-Term to Long-Term Scientific, Technological and Socio-Economic changes in the society, creating a more trustful and accessible environment for all, starting from best practices delivered by other EU projects, real user needs. It will help towards the fragmented EU media market due to the wealth of languages spoken in Europe, and the uneven deployment of language technologies in the many EU languages.

Europe may find hard to compete with social networks, but may become the best testbed for Media Accessibility services and research in all media formats given the cultural, social and linguistic reality:

- The number of coexisting EU languages

- Language sizes from large to minority languages

- The three writing alphabets (Latin, Greek and Cyrillic)

- The status of languages: from bilingual to multilingual

- Media translation approaches like subtitling, dubbing and voice-over

- The number of EU Sign Languages.

One of the features defining Europe is the many languages spoken at official (24) and unofficial levels (over 200). The reasons and impact for the choice of translation modality vary from political (Kilborne 1993, McLaughlin and Muñoz-Basols 2016), or as explained in (Rupérez et al 2015: 2) "dubbing tended to be adopted in larger countries, those whose national languages were widely used internationally, and those with dictatorial regimes. Smaller, democratic countries tended to adopt subtitling. No OECD country has moved from one to the other mode since WWII."

The different translation modalities also have a direct implication in education, with subtitling countries having better English skills than dubbing countries, and "subtitling, through better English skills, increases foreign direct investment and exports." (Rupérez et al 2015: 17). The choice of translation modality is also related to media genres. For example, documentaries are translated with voice-over and off-screen dubbing (Matamala 2009, Franco, Matamala and Orero 2012). The type of audience also impacts on the translation modality chosen. For example, children programmes must be dubbed in order to secure access to children under reading age.

Indeed, within its activities (including job creation on Media Accessibility), LEAD-ME Action will refer to the European Charter for Regional or Minority Languages, namely the European Convention for the protection and promotion of languages used by traditional minorities. Together with the Framework Convention for the Protection of National Minorities it constitutes the Council of Europe's commitment to the protection of national minorities. Regional or minority languages are part of Europe's cultural heritage and their protection and promotion contribute to the building of a Europe based on democracy and cultural diversity. 


\section{Accessible filmaking}

Accessibility used to be understood and studied from a clinical model (Orero and Tor-Carroggio 2018). This meant that audio description was created for blind and low sighted audience, and subtitles for the deaf and hard of hearing. This model has now moved to the Human Rights arena, where all people have the right to access to information and communication --and falls under the remit of Universal Design. Following this design principle, planning for accessibility requires to take place at the very moment of conception, and not as a postproduction activity away from the authors (Udon and Fels 2009). Romero Fresco (2013) developed further this accessible creative concept, looking at existing successful collaborations between: writer, director, actors and designers. He wrote and directed a movie Joining the Dots (2012) where the accessible filmmaking concept was fully developed. In fact, the use of subtitles in the film narrative (McClarthy 2012) has also given rise to the concept of creative subtitles. Research has also shown that audiences prefer this inclusive accessible filmmaking for audio description (Walzak and Fryer 2017). The reason is that it heightens engagement which is at the end of the day the objective of the author-audience dialogue. Other genres such as theatre has also tested this creative accessibility approach with positive results (Udo et al 2010).

\section{Conclusions}

In the information society access to information is now considered a Human Right, as developed in the Convention of Rights of People with Disabilities by United Nations. Movies and media content are these days the most popular and ubiquitous media, hence is the first target for its accessibility. It has been shown that accessibility should be taken into consideration at the very conception of the media content production, rather than the unsatisfactory and expensive after thought that is today. Romero Fresco (2013) has shown the way to go, and there are already courses on how to think accessible when producing media content.

In recent years the EU has been funding training courses for professionals in all media accessibility services and environments (Bartoll and Orero 2008, Matamala et al 2019a, Matamala and Orero 2019b, Oncins et al 2020, Matamala et al 2020, Orero et al 2020b). The next stage is to normalize the concept of accessible filmmaking. This will satisfy EU legislation, but beyond that it will make society more inclusive and diverse. It is in the diversity that Europe is united, and that should be reflected in EU movies and all the EU media industry.

\section{Acknowledgements}

The work in this article has been partially financed by the EU LEAD ME COST network (19142), the ERASMUS+ 2018-1-ES01-KA203050275 EASIT Easy Access For Social Inclusion Training, ERASMUS+ 2018-1-DE01-KA203-004218 LTA Quality Training in real time subtitling across EU and EU languages, ERASMUS+ 2019-1-FR01-KA204-062381 IMPACT Inclusive Method based on the Perception of Accessibility and Compliance Testing, ERASMUS + 2016-1-IT02KA203-024311ADLABPRO Audiodescription: A Laboratory for the development of a new professional profile, and the Catalan fund 2019SGR113.

\section{Filmography}

Joining the Dots. 2012. Pablo Romero-Fresco. United Kingdom,

Nota Texto: (Joining the Dots 2012)

Top of the Lake. 2013. Jane Campion. Australia. Nota Texto: (Top of the Lake 2013)

Volver. 2006. Pedro Almodovar. Spain.

Nota Texto: (Volver 2006)

\section{Bibliography}

Bartoll, Eduard and Pilar Orero. 2008. "Learning to subtitle online: learning environment, exercises, and evaluation". The Didactics of Audiovisual Translation. In Jorge Díaz Cintas (Ed.), 105-114. Amsterdam: Benjamins.

Nota Texto: (Bartoll and Orero 2008)

Brescia-Zapata, Marta. Forthcomin. Present and future of accessibility services in VR360 players. Intralinea.

Nota texto: (Brescia-Zapata forthcoming)

Egoyan, Atom and lan Balfour (2004). Subtitles: On the Foreignness of Film. Cambridge: MIT Press.

Nota Texto: (Egoyan and Balfour 2004)

Franco, Eliana, Anna Matamala and Pilar Orero. 2010. Voice-over Translation: An overview. Bern: Peter Lang.

Nota Texto: (Franco et al 2010)

Kilborn, R. 1993. "Speak my language: current attitudes to television subtitling and dubbing". Media, Culture and Society, 15(4): 641-660.

Nota Texto: (Kilburn 1993)

McLaughlin, M. and J. Muñoz-Basols. 2016. "Ideology, censorship and translation across genres: past and present." Perspectives, 24 (1), pp. 1-6.

Nota Texto: (McLaughlin and Muñoz-Basols 2016)

Mas, Lluis and Pilar Orero. 2018. New Subtitling Possibilities: Testing Subtitle Usability in HbbTV. Translation Spaces 7 (2): 263-284.

Nota Texto: (Mas and Orero 2018) 
Maszerowska, Anna, Anna Matamala and Pilar Orero. 2014. Audio Description. New perspectives illustrated. Amsterdam. John Benjamins.

Nota Texto: (Maszerowska et al 2014)

Matamala, Anna. 2009. "Translating documentaries: from Neanderthals to the Supernanny". Perspectives: Studies in Translatology 17(2): 93-107.

Nota Texto: (Matamala 2009)

Anna Matamala, Pilar Orero, Anna Jankowska, Carme Mangiron (2019a) Learning Audio Description: Training Resources for Future Academics and Professionals Cultus no. 12: 106-128.

Nota Texto: (Matamala et al 2019b)

Matamala, Anna and Pilar Orero (2019) "Training Experts in Inclusive Practices for an Equity on Access to Culture in Europe". In Vassilios Argyropoulos and Santoshi Hadler (eds) Inclusive Practices, Equity and Access: Perspectives of Educators across World. 263-280. London: Palgrave MacMillan.

Nota Texto: (Matamala et al 2019b)

Matamala, Anna, Pilar Orero, and Estel-la Oncins. 2020. EASIT: Training new professional profiles in easyto-understand audiovisual media services. Revista CIDIU, 2385-6203

Nota Texto: (Matamala et al 2020)

McClarty, Rebecca. 2012. "Towards a Multidisciplinary Approach in Creative Subtitling." Rosa Agost, Pilar Orero and Elena di Giovanni (eds) (2012). Monographs in Translating and Interpreting (MonTI) 4, 133-155.

Nota Texto: (McClarty 2012)

Oncins, Estel·la and Pilar Orero. 2020. "No audience left behind, one App fits all: an integrated approach to accessibility services." JOSTRANS 34. https://www. jostrans.org/issue34/art_oncins.pdf

Nota Texto: (Oncins and Orero 2020)

Oncins, Estel.la, Pilar Orero, and Anna Matamala. 2020. "The future of mediators for live events: LTA project academic and vocational training." Revista CIDIU, 2385-6203

Nota Texto: (Oncins et al 2020)

Orero, Pilar (forthcoming) Audio Description Personalisation. In Christopher Taylor and Elisa Perergo (Eds) The Routledge Handbook of Audio Description. London: Taylor Francis.

Nota Texto: (Orero forthcoming)

Orero, Pilar. 2021. Translation, Accessibility and Minorities. In Esperança Bielsa (ed.) The Routledge Handbook of Translation and Media. London: Taylor Francis.

Nota Texto: (Orero 2021)

Orero, Pilar and Irene Tor-Carroggio. 2018. "User requirements when designing learning e-content: interaction for all". In Evangelos Kapros and Maria Koutsombogera (eds), Designing for the User Experience in Learning Systems. 105-121. Springer

Nota Texto: (Orero and Tor-Carroggio 2018)
Orero, Pilar, Mario Montagud, Jordi Mata, Enric Torres, and Anna Matamala. 2020a. "Audio Subtitles or Spoken Subtitles: An ecological media accessibility service". In Dejica, Daniel and Carlo Eugeni, Anca Dejica-Cartis (eds.) Translation Studies and Information Technology - New Pathways for Researchers, Teachers and Professionals. 155-167. Timișoara: Editura Politehnica, Translation Studies Series.

Nota Texto: (Orero et al 2020a)

Orero, Pilar, Estel-la Oncins and Anna Matamala. 2020b. Web Accessiblity for All. Learning Materials towards the new EU Standard. Revista CIDIU. 2385-6203

Nota Texto: (Orero et al 2020b)

Romero-Fresco, Pablo. 2013. "Accessible filmmaking: Joining the dots between audiovisual translation, accessibility and filmmaking." The Journal of Specialised Translation 20. http://citeseerx.ist.psu.edu/viewdoc/downlo ad?doi=10.1.1.1061.1791\&rep=rep1\&type=pdf

Nota Texto: (Romero-Fresco 2013)

Rupérez, A., A. Bris and A. Banal-Estañol. 2015. "TV or not TV? The Economic Impact of Subtitling and English Skills" available at http://albertbanalestanol.com/wpcontent/uploads/Subtitles final.pdf

Nota Texto: (Rupérez et all 2015)

Udo, John-Patrick and Deborah Fels. 2009. "The Rogue Poster Children of Universal Design: Closed Captioning and Audio Description." Ted Rogers School of Information Technology Management Publications and Research, Paper 18, 1-32. http://digitalcommons.ryerson.ca/trsitm/18

Nota Texto: (Udo and Fels 2009)

Udo JP, Acevedo B, Fels DI. 2010. "Horatio audiodescribes Shakespeare's Hamlet: Blind and low-vision theatre-goers evaluate an unconventional audio description strategy." British Journal of Visual Impairment. 28(2):139156.

Nota Texto: (Udo et al 2010)

Walczak Agnieszka and Lousie Fryer. 2017. "Creative description: The impact of audio description style on presence in visually impaired audiences." British Journal of Visual Impairment. 35(1):6-17.

Nota Texto: (Walczak and Fryer 2017) 